\title{
Reproductive cycle and gonadal development of Donax striatus (Bivalvia: Donacidae) on an Amazon sandy beach in northern Brazil
}

\author{
Ewertton Gadelha ${ }^{1,2}$, Elton Silva ${ }^{1,2}$, Rosana Silva ${ }^{1}$, Shirley Rafael ${ }^{1}$, Fábio Pamplona ${ }^{1,2}$, \\ Glauber Palheta ${ }^{1,2}$, Nuno Melo ${ }^{1,2}$ \\ ${ }^{1}$ Federal Rural University of the Amazon, Avenida Tancredo Neves, 2501, Montese, 66077-830, Belém, Pará, Brazil. \\ (EG) E-mail: ewerttooo@yahoo.com.br. ORCID iD: https://orcid.org/0000-0002-5741-6547 \\ (ES) E-mail: eltonpesc@gmail.com. ORCID iD: https://orcid.org/0000-0002-7875-8466 \\ (RS) E-mail: nanarsa21@ hotmail.com.ORCID iD: https://orcid.org/0000-0001-6431-5042 \\ (SR) E-mail: shirley_rafael@outlook.com. ORCID iD: https://orcid.org/0000-0002-1831-4847 \\ (FP) E-mail: fbpamplona@yahoo.com.br. ORCID iD: https://orcid.org/0000-0001-7788-1035 \\ (GP) E-mail: gpalheta@gmail.com. ORCID iD: https://orcid.org/0000-0002-8032-8377 \\ (NM) (Corresponding author) E-mail: nunomelo@uol.com.br. ORCID iD: https://orcid.org/0000-0003-4163-4133 \\ ${ }^{2}$ Socio-environmental and Water Resources Institute, Postgraduate Programme in Aquaculture and Tropical Aquatic Re- \\ sources. UFRA, Belém, Pará, Brazil.
}

\begin{abstract}
Summary: The reproductive cycle and gonadal development of Donax striatus from a sandy beach in Ajuruteua, Amazon region, were studied. Monthly sampling took place from March 2015 to April 2016. Histological analysis was performed on 420 individuals, and the oocyte diameters were determined from histological sections and used to determine the reproductive period. The population showed a balanced sex ratio (1:1) with a size at first maturity of $10.9 \mathrm{~mm}$ in males and $8.9 \mathrm{~mm}$ in females. The population showed r-strategist characteristics and continuous spawning, and the reproductive cycle showed no seasonal variation or significant relation with any environmental parameter. The organic matter was significantly higher in the rainy season. According to the generalized linear model analysis (GLM), only the condition index (CI) had a significant relationship with the organic matter of the sediment. The type of reproductive strategy adopted by D. striatus corroborates the global breeding hypotheses for species of tropical environments. For conservation, it should be recommended to harvest this species at a shell length above $13 \mathrm{~mm}$.
\end{abstract}

Keywords: gametogenesis; reproduction; bivalves; tropical sandy beaches; size at first maturity.

Ciclo reproductivo y desarrollo gonadal del Donax striatus (Bivalvia: Donacidae) en una playa de arena del Amazonas em el norte de Brasil

Resumen: Un estudio del ciclo reproductivo y desarrollo gonadal de Donax striatus fue realizado en una playa arenosa localizada en Ajuretueua, región amazónica brasileira. Entre marzo de 2015 y abril de 2016 se realizaron muestreos mensuales. El análisis histológico fue realizado en 420 individuos, determinando los diámetros de los ovocitos en secciones histológicas y usándolos para determinar el periodo reproductivo. La población presentó una proporción sexual equilibrada (1:1) encontrando la primera maduración sexual en machos con $10.9 \mathrm{~mm}$ y en hembras con $8.9 \mathrm{~mm}$. La población presentó características de estrategias r; desove constante y un ciclo reproductivo sin variaciones en los periodos climáticos, no encontrando relaciones significativas con los parámetros ambientales. La materia orgánica fue significativamente alta en la estación lluviosa. De acuerdo con el análisis MLG únicamente el Índice de Condición (IC) tuvo una relación significativa con la materia orgánica del sedimento. El tipo de estrategia reproductiva adoptada por $D$. striatus corrobora la hipótesis global de reproducción para especies de ambientes tropicales. Para la conservación de la especie debe recomendarse la recolección de individuos de talla superior a $13 \mathrm{~mm}$.

Palabras clave: gametogénesis; reproducción; bivalvos; playas arenosas tropicales; talla de la primera maduración sexual.

Citation/Como citar este artículo: Gadelha E., Silva E., Silva R., Rafael S., Pamplona F., Palheta G., Melo N. 2019. Reproductive cycle and gonadal development of Donax striatus (Bivalvia: Donacidae) on an Amazon sandy beach in northern Brazil. Sci. Mar. 83(1): 31-39. https://doi.org/10.3989/scimar.04823.15A

Editor: M. Gaspar.

Received: June 22, 2018. Accepted: January 7, 2019. Published: February 27, 2019.

Copyright: ( 2019 CSIC. This is an open-access article distributed under the terms of the Creative Commons Attribution 4.0 International (CC BY 4.0) License. 


\section{INTRODUCTION}

Since 1950, invertebrate fisheries have rapidly expanded on multiple scales, and today operate around the world (Anderson et al. 2011), increasing the need for research into bivalve reproduction to establish management plans for effective conservation programmes (Quayle 1943, Galvão et al. 2006). Regarding bivalve aquaculture, research on the reproductive cycle reveals the periods when seed can be collected (Nascimento and Lunetta 1978, Galvão et al. 2006).

According to Mackie (1984), reproductive cycles are affected by the interaction of genetic and environmental factors, resulting in reproductive activity, and can be classified as (1) k-strategist, with short, limited reproductive periods, and (2) r-strategist, with reproductive activity that occurs during most of the year (Fretter 1984).

Reproductive patterns of bivalves vary according to their geographic location (climatic region), which can be attributed to the environmental variations of each region associated with extreme climatic events, which prompt species with diversified strategies to optimize their reproduction, for example, through the rapid proliferation of mature gametes and continuous spawning limited to certain periods (Cárdenas and Aranda 2000).

Giese (1959) and Defeo and Cardoso (2002) suggested that marine invertebrates have a limited reproductive period in the polar regions and a longer period in tropical regions. For example, in the tropics, where planktonic food is continuously available along the coastal margins, the reproductive period is not limited by food availability.

Among bivalve species, those in the genus Donax belong to a globally dominant group in invertebrate communities on sandy beaches. A total of 88 donacid species have been described to date, around $75 \%$ of them found in tropical waters, and $22 \%$ in temperate waters (McLachlan and Brown 2006, WORMS 2018).

However, although this genus is among the most abundant on sandy beaches, few studies have been made of their reproductive biology in tropical regions, as highlighted by Gil and Thomé (2004a, b), Riascos and Urban (2002), and Riascos (2006). Therefore, the present study aimed to describe the reproductive cycle and gametogenesis, and to estimate the size at sexual maturity of $D$. striatus from sandy beaches of Ajuruteua, northeast Pará in the Brazilian Amazon.

\section{MATERIALS AND METHODS}

\section{Study area and sampling}

Donax striatus were collected on Ajuruteua Beach, northeast Pará (0049'57'S; 46³6'01'”W) (Fig. 1), with a rainy season between December and May, a dry season between June and November, and a regime of semidiurnal macrotides (4-6 m). The beach showed dissipative characteristics, with 200 to $300 \mathrm{~m}$ low tides, sediment with a fine grain size, and strong energy waves (Martorano et al. 1993, Alves and El-Robrini 2006).

Sampling was performed monthly during the syzygy low tide from March 2015 to April 2016, and 30

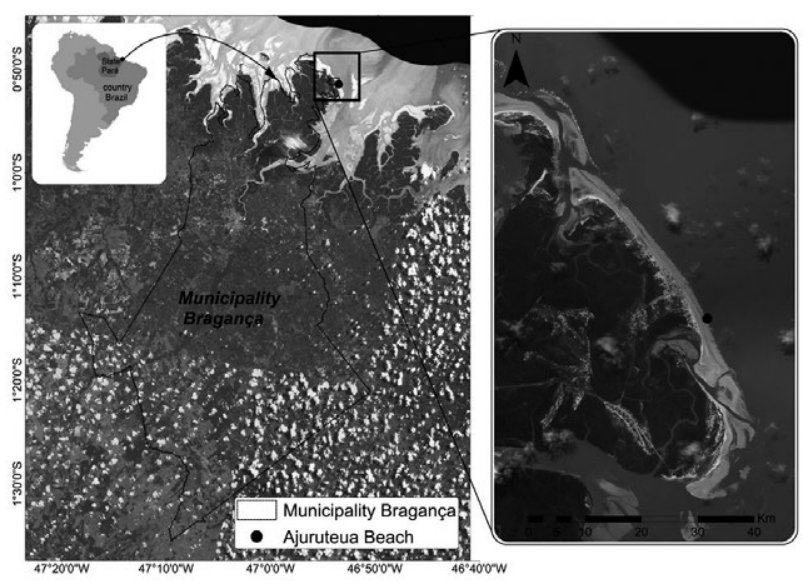

Fig. 1. - Map of the study area, Ajuruteua sandy beach, Bragança, Pará, Brazil.

individuals were randomly collected along the beach. Subsequently, each individual was measured for shell length (SL) with a caliper and weighed for total weight and soft parts wet weight using a digital balance to $0.01 \mathrm{~g}$. To convert the soft parts dry weight to ash-free dry mass (AFDM), the specimens were dried for $12 \mathrm{~h}$ at $90^{\circ} \mathrm{C}$ then subjected to ignition in a muffle oven at $550^{\circ} \mathrm{C}$ for $24 \mathrm{~h}$ (Brey 1986).

\section{Environmental variables}

Simultaneously, during the sampling surveys the environmental variables at the beach were measured, including sea surface temperature (SST), with a digital thermometer with a precision of $0.1^{\circ} \mathrm{C}$, and salinity, with a portable refractometer with a scale of $1 / 100$. The National Meteorology Institute provided precipitation data. The sediment organic matter was analysed through the ignition methodology proposed by Dean (1974). Seawater was collected at the beach using a polyethylene bottle and refrigerated for further analysis of chlorophyll $a$ following the methodology of CETESB (2014).

\section{Histological analysis and condition index}

For the histological analysis, the visceral mass was removed from the shell and immersed in a salty Davidson solution for $24 \mathrm{~h}$. Subsequently the gills, labial palps, and mantle border were also removed and the gonads were transferred to $70 \%$ alcohol. In the laboratory, the modified histological method of Junqueira and Junqueira (1983) was used. Transverse $5 \mu \mathrm{m}$ sections were sliced using a manual microtome. Gonad sections of $D$. striatus were examined using a binocular microscope; five stages of gonadal development were observed, and were identified and characterized based on the morphological and cytological criteria described by Narchi (1976) for Anomalocardia fluxuosa and Herrmann et al. (2009) for D. hanleyanus. Photomicrographs of histological sections were captured using Motic Image Plus 2.0, to determine the oocyte number and average oocyte diameter following the methodology described by Herrmann et al. (2009), using Image Tool 3.0 software. 
According to Boehs et al. (2008), the condition index (CI) could provide information related to the processes of glycogen conversion in gametes, sexual maturation and gamete release, using the following formula:

$$
\mathrm{CI}=(\mathrm{SPWW} / \mathrm{TWW}) \times 100
$$

where CI is the condition index, SPWW is the soft parts wet weight and TWW is the total wet weight.

\section{Size at first maturity}

The size at which $50 \%$ of the individuals in the population are sexually mature (adults) was estimated from the Galton ogive, and from the proportion of mature males and females (stage II, maturation; stage III, Ripe; stage IV, spawning; and stage V, cytolysis) in different size classes, using the logistic equation according to McCullagh and Nelder (1989):

$$
\mathrm{SL}_{50}=\frac{\mathrm{a}}{1-e\left[-\left(\mathrm{x}-\mathrm{x}_{0}\right) / \mathrm{b}\right]}
$$

where $\mathrm{SL}_{50}$ is the proportion of females and males with mature gonads in each size class (SL) and $a, b$ and $x_{0}$ are parameters.

The size at first maturity was estimated by plotting the frequency of maturation $(\mathrm{Y})$ against the size class (X), generating a sigmoid, where an abscissa was traced at the point corresponding to $50 \%$ until it intersects the curve. This meeting point corresponds in the $\mathrm{x}$-axis to the size at first maturity. The above equation was adjusted by non-linear least squares using the quantum Newton algorithm of the SigmaPlot software package, version 11 (2008).

\section{Statistical analyses}

The assumptions of normality and homoscedasticity of the environmental and biological data were tested by Kolmogorov-Smirnov and Levene tests, respectively. All results were considered statistically significant at $\alpha \leq 0.05$. From the analysed variables, only oocyte abundance, ripe and spawning stages met these assumptions, so the t-test was carried out to verify differences between the dry and wet seasons.

The nonparametric Mann-Whitney (U) test was applied when the assumptions of parametric tests were not met with either raw or transformed data. Therefore, this test was employed on AFDM, CI, oocyte diameter and environmental variables also to compare mean values between seasons.

The generalized linear model (GLM) was used to examine the relationships between CI, biomass, oocyte abundance, ripe and spawning stages and the explanatory variables (SST, salinity, precipitation, chlorophyll $a$ and sediment organic matter). The GLM was constructed using a Gaussian model identity link function. The Akaike information criterion (AIC) (Akaike 1973) was used to compare the models, with lower values indicating a more parsimonious model than a model fit with a higher AIC.
The population sex ratio was compared between seasons using the chi-square test $\left(\chi^{2}\right)$. The t, MannWhitney and chi-square tests were performed with the PAST software, version 3.02 (Hammer et al. 2001), while the GLM was carried out using the open R software, version 3.4.3 (R Core Team 2017).

\section{RESULTS}

\section{Environmental variables}

During the study period, when there was no rainfall (September to December 2015), the SST at the beach reached a maximum of $36^{\circ} \mathrm{C}$ (October 2015), the salinity was 36 (September 2015), and chlorophyll $a$ reached $3.7 \mathrm{mg} \mathrm{m}^{-3}$ (December 2015); however, the organic matter peaked during the rainy season in January 2016 at $2.6 \%$ (Fig. 2). The organic matter was significantly higher in the rainy season $(\mathrm{U}=0.0023 ; \mathrm{p}<0.05)$, and SST, chlorophyll $a$ and salinity were not significantly different between seasons $(\mathrm{U}=0.4954, \mathrm{U}=0.3518$ and $\mathrm{U}=0.1293$, respectively; $\mathrm{p}>0.05$ ).

\section{Sexual ratio}

During the study period, 420 individuals were analysed, of which 207 were females (52\%) and $193(48 \%)$ were males, with their size range varying from $2.8 \mathrm{~mm}$ to

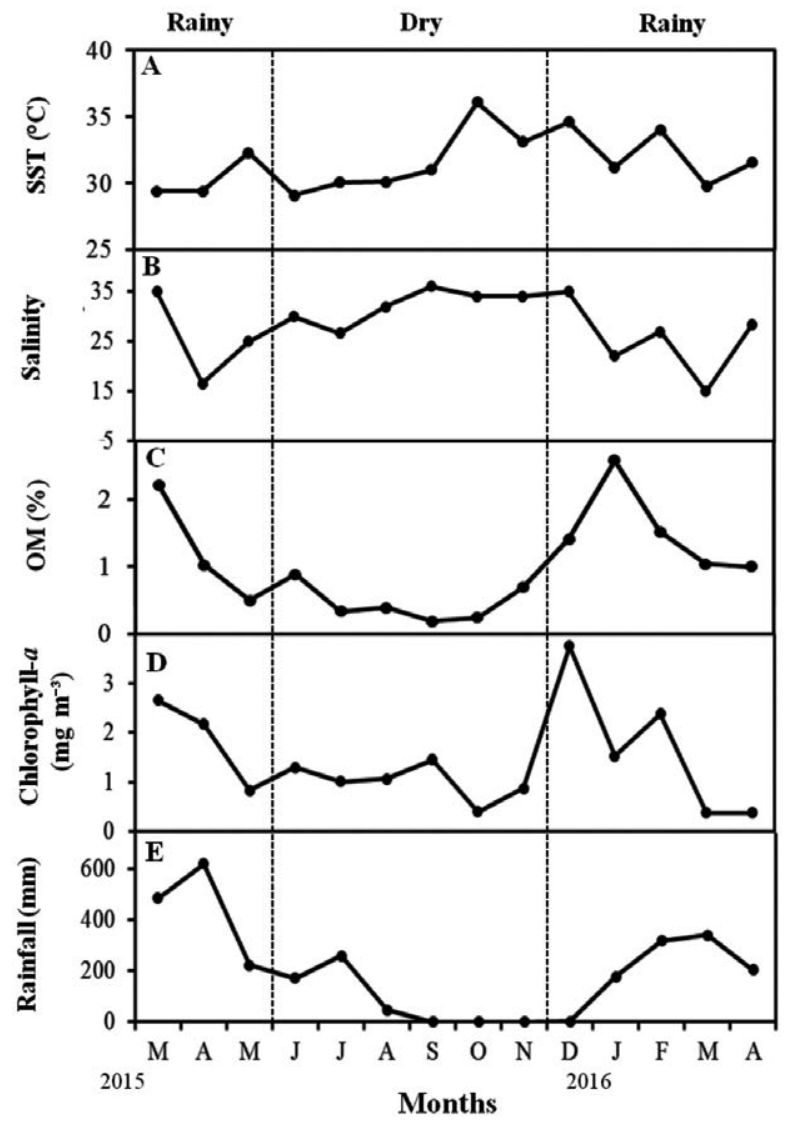

Fig. 2. - Variation in environmental variables at the tropical beach. A, sea surface temperature, $\mathrm{SST}\left({ }^{\circ} \mathrm{C}\right)$; B, salinity; C, organic matter, $\mathrm{OM}(\%)$; D, chlorophyll $a\left(\mathrm{mg} \mathrm{m}^{-3}\right)$; and $\mathrm{E}$, rainfall $(\mathrm{mm})$ during the study period. 


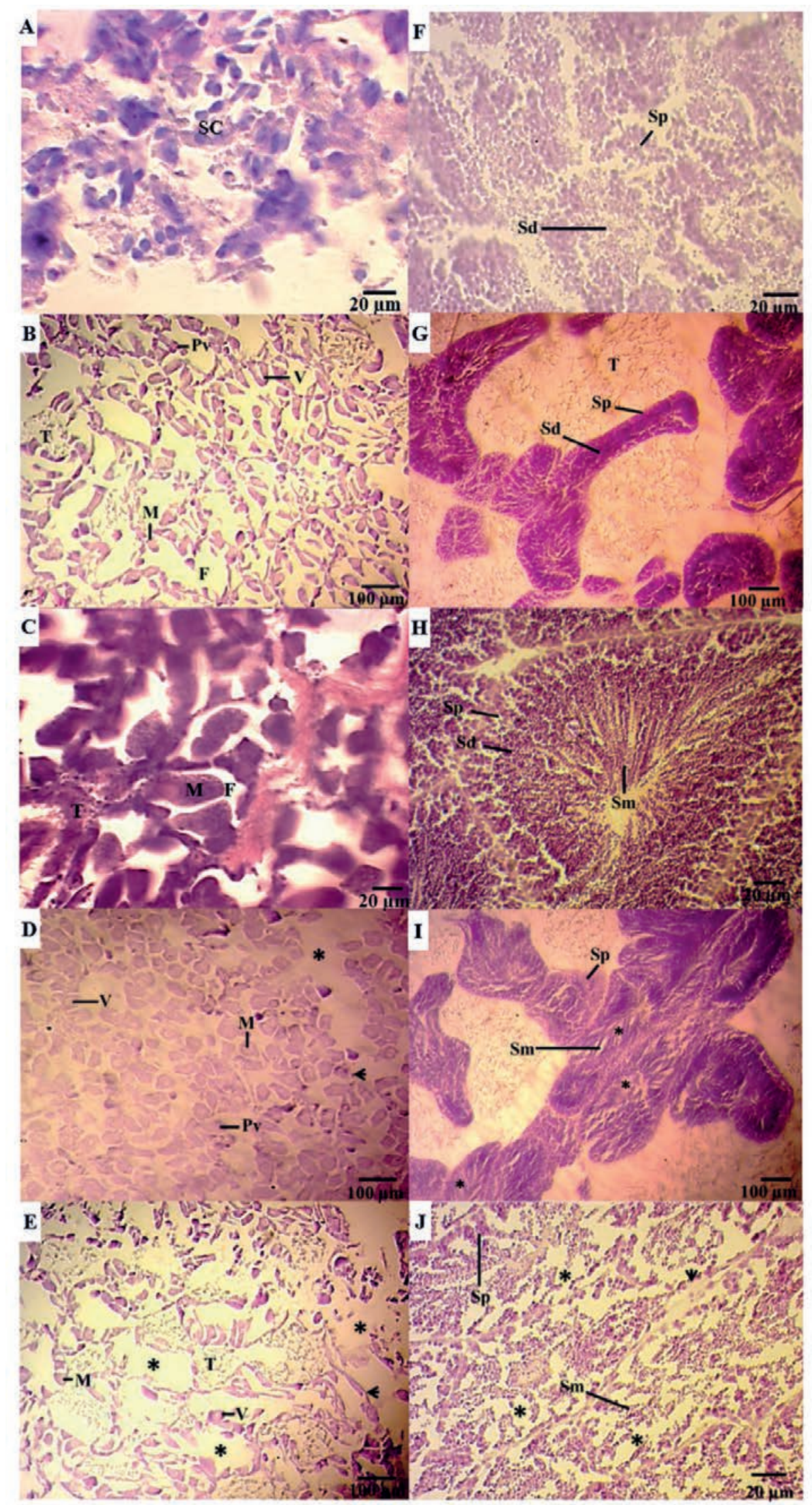

Fig. 3. - Photomicrographs of the gonadal development stages in Donax striatus. A, immature female; B, female in maturation; C, ripe female; D, spawning female; E, female in cytolysis; F, immature male; G, male in maturation; H, ripe male; I, spawning male; J, male in cytolysis; SC, stem cell; PV, pre-vitellogenic oocytes; M, mature oocyte; V, vitellogenic oocyte; F, ovarian follicle; T, interfollicular tissue; Sm, spermatozoa; Sp, spermatocyte; Sd, spermatid; T, interfollicular tissue; * indicates empty spaces with the release of mature gametes and the arrows indicate the follicular wall. 
$39.1 \mathrm{~mm}$ SL. There was no significant difference in the sex ratio of the samples ( $p>0.05)$, which showed a balanced proportion of $1 \mathrm{M}: 1 \mathrm{~F}\left(\chi^{2}=0.49 ; \mathrm{p}>0.05\right)$. Monthly there were no differences in the sex ratio, except in April 2016, when females $(67 \%)$ were significantly more abundant than males $(33 \%)\left(\chi^{2}=3.33 ; \mathrm{p}<0.05\right)$.

\section{Gonadal development stages}

Based on the microscopic images of the gonadal tissues, five stages of gonadal development of males and females of D. striatus were assigned and described: I, immature; II, maturation; III, ripe; IV, spawning; and $\mathrm{V}$, cytolysis.

In females, the immature stage was characterized by ovarian follicle formations, with clusters of mother cells adhering to the follicular wall, and a low frequency of basophil oocytes (Fig. 3A). The maturation stage showed different phases of germinative cells, with the predominance of basophils and pre-vitellogenic and vitellogenic oocytes, while mature cells had lower frequency; however, the ovarian follicles were well delimited, with thin walls (Fig. 3B). The ripe stage was characterized by different phases of germinative cells, but there was a high frequency of mature oocytes and the follicles had relatively large diameters, with the follicle wall distended, and a considerable quantity of oocytes within the follicles (Fig. 3C).

In the spawning stage the follicular wall had interfollicular tissue, and fewer cells in pre-vitellogenic, vitellogenic and mature stages were observed, leaving spaces within the ovarian follicles (Fig. 3D). The cytolysis stage was characterized by a thick follicular wall, and the ovarian follicles were empty or with residuals cells, showing a proliferation of new cells (Fig. 3E).

In males, the immature stage was characterized by the presence of only mother cells and the beginning of testicular tube formation, and gametes in the spermatogonia and spermatocyte stages (Fig. 3F). In the maturation stage, the testicular tubes were already fully formed, with the presence of germ cells in spermatogonia, spermatid and spermatocyte phases. The number of spermatozoa, when present, were reduced and dispersed in the testicular lumen (Fig. 3G). In the ripe stage, there were increased gametogenic processes, including all phases of germ cells, with a predominance of spermatozoa in the centre of the testicular tubes. The testicular tubes had a relatively large diameter with limited internal space (Fig. $3 \mathrm{H}$ ).

In the spawning stage, the spermatozoa were expelled, leaving empty spaces in the testicular tubes. The tube diameter was reduced and no follicular wall was observed (Fig. 3I). In the cytolysis stage, most spermatozoa had been expelled from the testicular tubes; interfollicular tissue with stem cells or spermatogonia was observed, and the walls of tubules were considerably reduced (Fig. 3J).

\section{Seasonal variation of condition index and biomass}

The monthly mean CI ranged from $6.9 \%$ to $15.5 \%$ (11.1 \pm 4.7$)$ and AFDM ranging from 0.005 to $0.009 \mathrm{~g}$

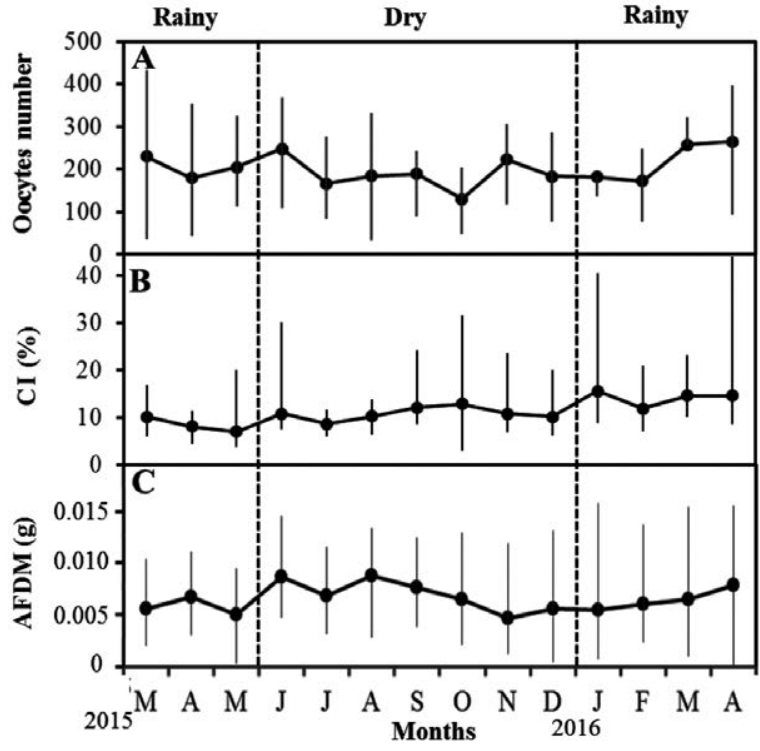

Fig. 4. - A, monthly variation of the mean number of oocytes; B, mean condition index $(\%)$; and $\mathrm{C}$, mean ash-free dry mass $(\mathrm{g})$ of Donax striatus during the study period.

(0.0065 \pm 0.0031$)$ (Fig. 4B, C). According to the GLM, the CI only had a significant relationship with the sediment organic matter ( $\mathrm{t}$ value $=2.935, \mathrm{p}=0.0188$ ) (Table 1). However, the AFDM showed a slight increase in the dry season, being significantly higher than in the rainy season $(\mathrm{U}=0.056, \mathrm{p}<0.05)$, which may have occurred due to a higher frequency of mature individuals. The CI showed no difference between seasons $(\mathrm{U}=0.2468$, $\mathrm{p}>0.05$ ), confirming that the reproduction was not seasonal.

\section{Reproductive cycle}

In the histological analysis, the presence of distinct stages of gonadal development was observed in most months, so the reproductive cycle of $D$. striatus could be characterized as continuous. Both sexes showed the spawning stage throughout the study period, indicating continuous spawning.

Higher proportions of mature females (August and November 2015) and mature males (July to October 2015) occurred during the dry season. Higher occurrences of spawning stages occurred in females in May and September 2015 and January and February 2016, and in males between March and May 2015 and December 2015 and February 2016. Therefore, a higher incidence of spawned individuals was observed in the rainy season. Immature phases were more frequent in females in October to November 2015 and in males in May 2015 (Fig. 5). Therefore, the probable recruitment of the species occurred in these periods.

During the study period, the mean oocyte diameter in distinct stages of gonadal development were 20.8, $21.2,23.2,19.8$, and $21.6 \mu \mathrm{m}$ for the immature, maturation, ripe, spawning and cytolysis stages, respectively (Table 2). There was no significant difference between seasons $(\mathrm{U}=0.64179 ; \mathrm{p}>0.05)$. It was observed during the study period that the maturation stage in all the 
Table 1. - Estimated coefficient and standard error (SE) of generalized linear model routines, applied to the dependent variables: A, condition index (CI); B, biomass; C, oocyte number; D, ripe stage; and E, spawning stage as a function of the independent parameters sea surface temperature (SST), salinity, organic matter, precipitation and chlorophyll $a$. Bold values, $\mathrm{p}<0.05$.

\begin{tabular}{|c|c|c|c|c|c|}
\hline & Estimate & SE & t value & $\mathrm{p}$ & AIC \\
\hline A: CI & & & & & 65.811 \\
\hline SST & 0.062495 & 0.317502 & 0.197 & 0.8489 & \\
\hline Salinity & -0.057645 & 0.124364 & -0.464 & 0.6553 & \\
\hline Organic matter & 2.916150 & 0.993475 & 2.935 & 0.0188 & \\
\hline Precipitation & -0.006895 & 0.004908 & -1.405 & 0.1977 & \\
\hline Chlorophyll $a$ & -1.535513 & 0.785155 & -1.956 & 0.0862 & \\
\hline B: Biomass (AFDW) & & & & & -141.41 \\
\hline SST & $-3.732 \mathrm{e}^{-04}$ & $1.939 \mathrm{e}^{-04}$ & -1.925 & 0.0904 & \\
\hline Salinity & $1.192 \mathrm{e}^{-05}$ & $7.595 \mathrm{e}^{-05}$ & 0.157 & 0.8792 & \\
\hline Organic matter & $-6.525 \mathrm{e}^{-04}$ & $6.067 \mathrm{e}^{-04}$ & -1.076 & 0.3135 & \\
\hline Precipitation & $-1.721 \mathrm{e}^{-06}$ & $2.997 \mathrm{e}^{-06}$ & -0.574 & 0.5815 & \\
\hline Chlorophyll $a$ & $1.906 \mathrm{e}^{-05}$ & $4.795 \mathrm{e}^{-04}$ & 0.040 & 0.9693 & \\
\hline C: Oocytes number & & & & & 148.56 \\
\hline SST & -8.994917 & 6.098944 & -1.475 & 0.1785 & \\
\hline Salinity & 0.941107 & 2.388935 & 0.394 & 0.7039 & \\
\hline Organic matter & 20.466414 & 19.083816 & 1.072 & 0.3148 & \\
\hline Precipitation & -0.009265 & 0.094272 & -0.098 & 0.9241 & \\
\hline Chlorophyll $a$ & -15.543812 & 15.082168 & -1.031 & 0.3329 & \\
\hline D: Ripe stage & & & & & 84.217 \\
\hline SST & -0.335324 & 0.612669 & -0.547 & 0.599 & \\
\hline Salinity & 0.392138 & 0.239980 & 1.634 & 0.141 & \\
\hline Organic matter & -0.430575 & 1.917064 & -0.225 & 0.828 & \\
\hline Precipitation & 0.005701 & 0.009470 & 0.602 & 0.564 & \\
\hline Chlorophyll $a$ & -0.338118 & 1.515078 & -0.223 & 0.829 & \\
\hline E: Spawning stage & & & & & 88.358 \\
\hline SST & 1.305067 & 0.710326 & 1.837 & 0.103 & \\
\hline Salinity & -0.391492 & 0.278232 & -1.407 & 0.197 & \\
\hline Organic matter & -0.536894 & 2.222637 & -0.242 & 0.815 & \\
\hline Precipitation & -0.002358 & 0.010980 & -0.215 & 0.835 & \\
\hline Chlorophyll $a$ & 1.558124 & 1.756577 & 0.887 & 0.401 & \\
\hline
\end{tabular}

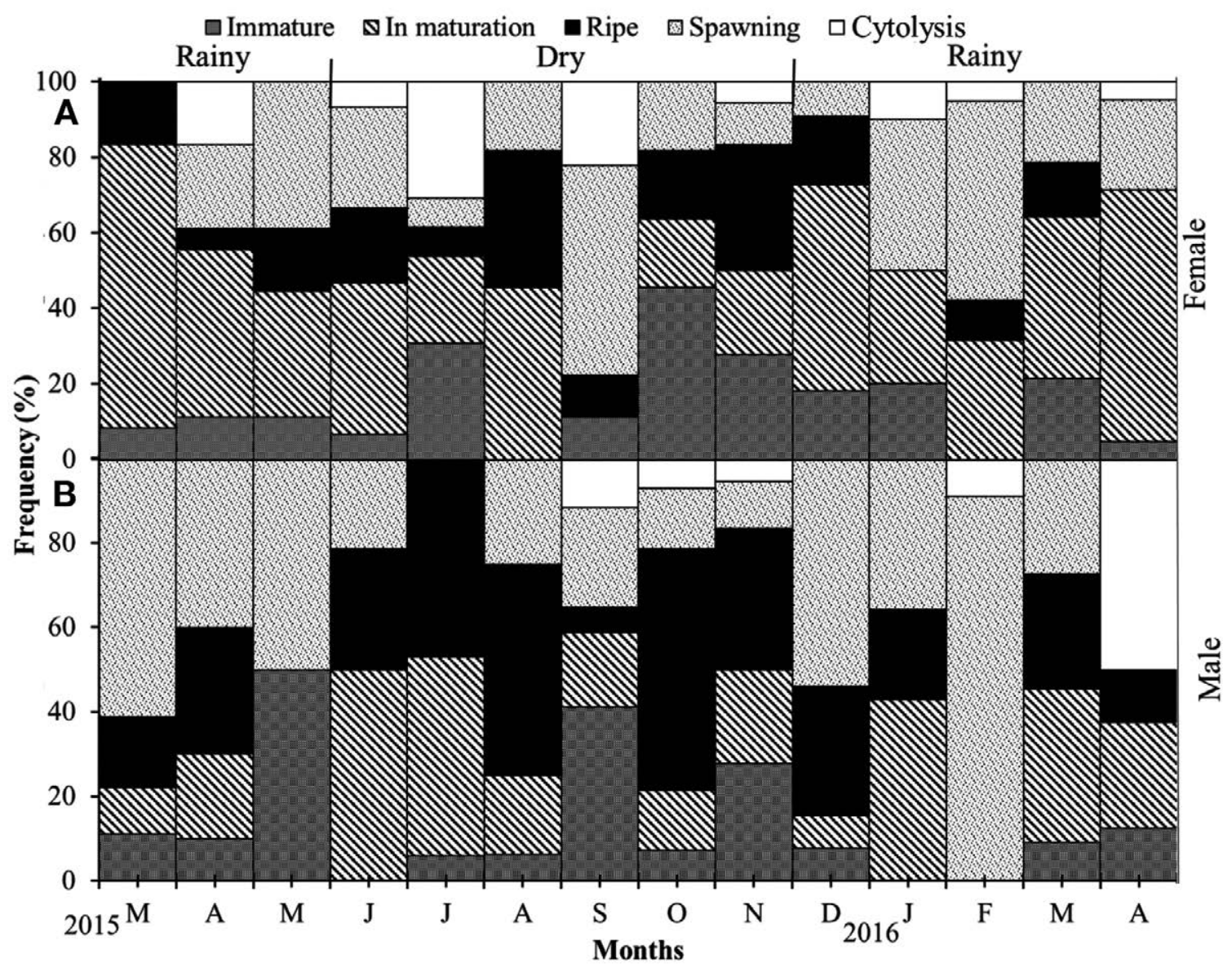

Fig. 5. - Frequency of maturation stages in females (A) and males (B) of Donax striatus during the study period. 
Table 2. - Oocyte diameters of Donax striatus (mean \pm standard deviation; min-max). Gonad developmental stages: IM, immature; $\mathbf{M}$, maturation; RI, ripe; SP, spawning; and CT, cytolysis.

\begin{tabular}{|c|c|c|c|c|c|}
\hline Year & Month & $\begin{array}{c}\text { Develop- } \\
\text { mental } \\
\text { Stage }\end{array}$ & $\begin{array}{c}\text { Sample } \\
\text { size }\end{array}$ & $\begin{array}{c}\text { Mean } \pm \text { standard } \\
\text { deviation }(\mu \mathrm{m})\end{array}$ & $\begin{array}{c}\text { Range } \\
(\min -\max ) \\
(\mu \mathrm{m})\end{array}$ \\
\hline \multirow[t]{33}{*}{2015} & \multirow[t]{3}{*}{ Mar } & IM & 32 & $25.4 \pm 7.8$ & 11.4-41 \\
\hline & & IN & 589 & $17.9 \pm 8.9$ & $3-57.3$ \\
\hline & & RI & 328 & $25.1 \pm 9.9$ & $5.9-66.9$ \\
\hline & \multirow[t]{5}{*}{ Apr } & IM & 14 & $22.3 \pm 7.6$ & $16.5-38$ \\
\hline & & IN & 125 & $21.4 \pm 6.8$ & $8.1-41.4$ \\
\hline & & RI & 45 & $24.3 \pm 5.6$ & $15.3-37$ \\
\hline & & SP & 98 & $22.8 \pm 7.3$ & $9-39.3$ \\
\hline & & $\mathrm{CT}$ & 68 & $21.2 \pm 6.0$ & $9.7-34.4$ \\
\hline & \multirow[t]{4}{*}{ May } & IM & 113 & $19.7 \pm 6.8$ & $8.1-41.4$ \\
\hline & & M & 349 & $19.7 \pm 7.2$ & 8.1-41.4 \\
\hline & & RI & 244 & $18.4 \pm 7.5$ & $15.3-37.0$ \\
\hline & & SP & 653 & $17.2 \pm 7.5$ & $9.0-39.3$ \\
\hline & \multirow[t]{4}{*}{ Jun } & M & 319 & $20.3 \pm 7.3$ & $5.7-40.3$ \\
\hline & & RI & 199 & $21.1 \pm 7.7$ & $8.1-47.0$ \\
\hline & & SP & 338 & $20.9 \pm 5.8$ & $9.0-39.3$ \\
\hline & & CT & 56 & $11.5 \pm 4.7$ & $5.9-26.9$ \\
\hline & \multirow[t]{3}{*}{ Jul } & SP & 19 & $11.2 \pm 3.8$ & $7.0-18.7$ \\
\hline & & M & 62 & $16.1 \pm 5.9$ & $6.1-28.3$ \\
\hline & & CT & 78 & $13 \pm 4.7$ & $5.7-26.9$ \\
\hline & \multirow[t]{3}{*}{ Aug } & M & 123 & $21.2 \pm 8.0$ & $7.6-39.3$ \\
\hline & & RI & 82 & $23.2 \pm 7.7$ & $9.1-37.2$ \\
\hline & & CT & 57 & $24.4 \pm 7.5$ & $10.6-37.1$ \\
\hline & \multirow[t]{2}{*}{ Sep } & CT & 28 & $24.9 \pm 7.1$ & $14.9-46.3$ \\
\hline & & M & 39 & $28.6 \pm 5.7$ & $16.6-37.8$ \\
\hline & \multirow[t]{3}{*}{ Oct } & M & 33 & $19.6 \pm 5.4$ & $12.6-30.7$ \\
\hline & & CT & 68 & $25.4 \pm 6.9$ & $14.3-52.9$ \\
\hline & & RI & 18 & $29.6 \pm 6.9$ & $21.4-41.7$ \\
\hline & \multirow[t]{4}{*}{ Nov } & RI & 44 & $30.6 \pm 7.7$ & $16.9-48.5$ \\
\hline & & IM & 52 & $25.3 \pm 7.8$ & $14.3-45.5$ \\
\hline & & IN & 23 & $25.2 \pm 7.0$ & $15.4-37.5$ \\
\hline & & SP & 24 & $25.2 \pm 7.3$ & $14.5-37.5$ \\
\hline & \multirow[t]{2}{*}{ Dec } & M & 50 & $25.9 \pm 7.36$ & $9.3-39.3$ \\
\hline & & RI & 51 & $30.2 \pm 6.2$ & $12.9-42.1$ \\
\hline \multirow[t]{9}{*}{2016} & Jan & SP & 41 & $26.7 \pm 4.8$ & $17.2-34.2$ \\
\hline & \multirow[t]{3}{*}{ Feb } & M & 169 & $22.6 \pm 6.1$ & $10.4-46.9$ \\
\hline & & RI & 43 & $26.5 \pm 6.2$ & $17.3-41.6$ \\
\hline & & $\mathrm{CT}$ & 256 & $25.7 \pm 6.0$ & $11.8-44.0$ \\
\hline & Mar & M & 41 & $25.9 \pm 5.6$ & $15.2-36.4$ \\
\hline & \multirow[t]{4}{*}{ Apr } & M & 1240 & $22.8 \pm 7.0$ & $5.4-45.1$ \\
\hline & & SP & 375 & $22.1 \pm 7.3$ & $5.9-48.9$ \\
\hline & & $\mathrm{CT}$ & 59 & $16.4 \pm 5.4$ & $7.1-29.1$ \\
\hline & & IM & 18 & $19.1 \pm 7.6$ & $10.4-32.2$ \\
\hline
\end{tabular}

germinative cell lines shows continuous maturation, revealing a reproductive strategy throughout the study period that has no direct correlation with the environmental variables.

Oocyte diameters varied from 3 to $66 \mu \mathrm{m}$, with the histograms showing that the size intervals with highest frequencies were 18 to 23 and 23 to $28 \mu \mathrm{m}$, with no clear reduction from these sizes throughout the study period (Fig. 6).

The highest and lowest oocyte abundance occurred in October 2015 and April 2016, respectively (Fig. 4A). The abundance of oocytes showed no significant relationships with environmental parameters (Table 1 ), and the t-test revealed that oocyte number was not affected seasonally, further confirming a continuous reproductive cycle $(\mathrm{t}=0.0538 ; \mathrm{p}>0.05)$.

\section{Size at sexual maturity}

According to the method of the logistic equation of the Galton ogive (McCullagh and Nelder 1989), sexual maturity occurred in females at $8.9 \mathrm{~mm}$ length and in males at $10.9 \mathrm{~mm}$ length. When the sexes are

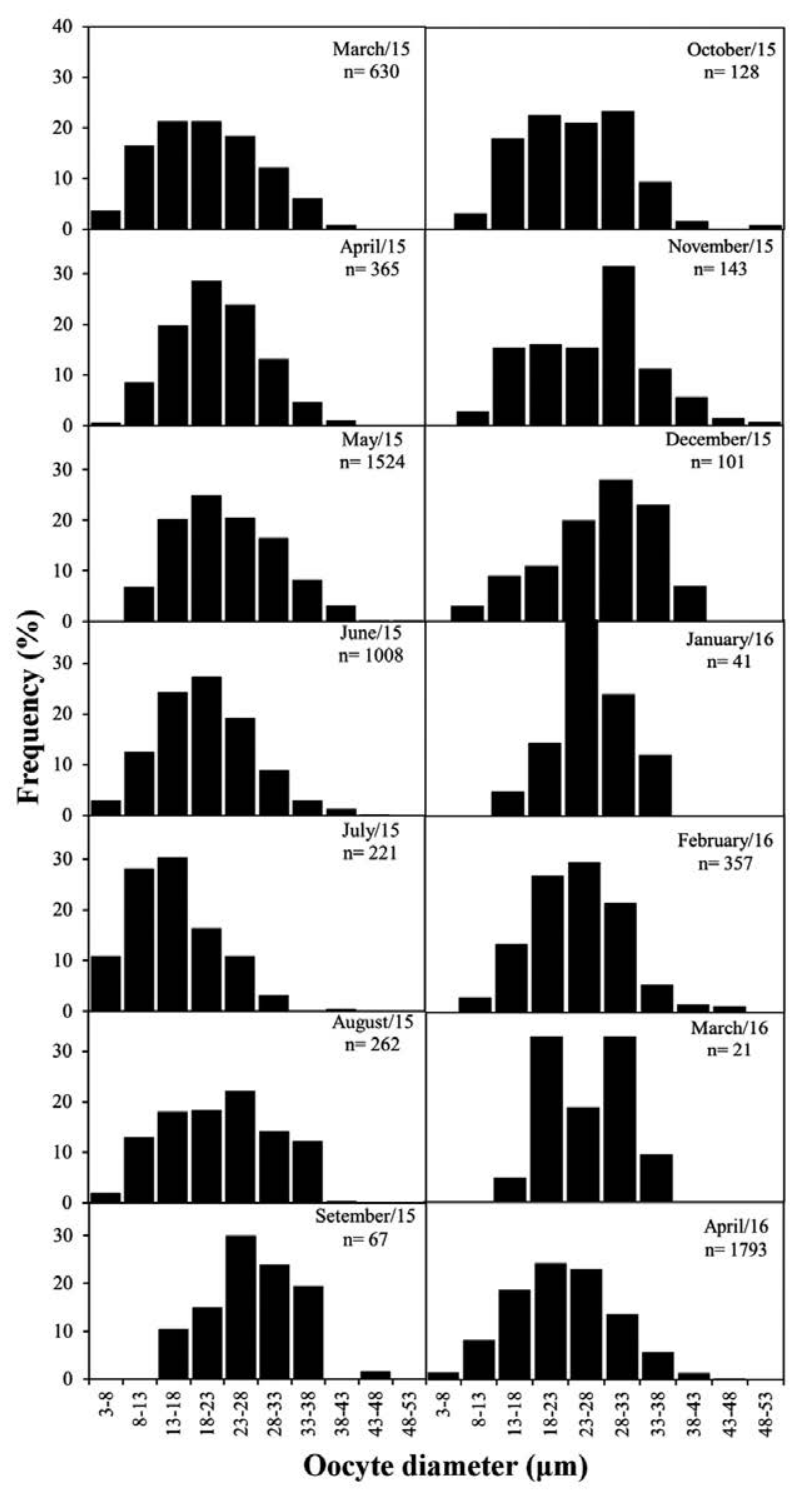

Fig. 6. - Monthly distribution of the absolute frequency of oocyte diameters in Donax striatus.

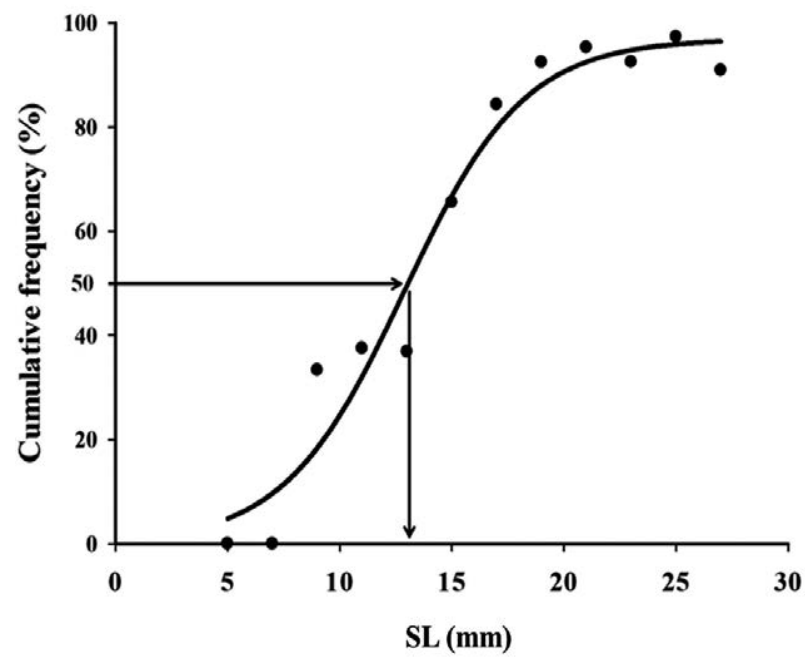

Fig. 7. - Logistic curve indicating the average size at first maturity in Donax striatus. 
grouped, it is estimated that the population will become reproductively active at $12.5 \mathrm{~mm}$ length. The second method used to calculate the first sexual maturity size, the logistic curve, confirmed that $D$. striatus begins to mature between 10 and $15 \mathrm{~mm}$ length (Fig. 7).

\section{DISCUSSION}

The D. striatus population of the dissipative sandy beach starts sexual maturity at $12.5 \mathrm{~mm}$, similar to the length of $12 \mathrm{~mm}$ found by Gil and Thomé (2004b) for D. hanleyanus in Rio Grande do Sul, Brazil. In temperate environments of Argentina, according to Herrmann et al. (2009), D. hanleyanus started maturation at $8 \mathrm{~mm}$ (on a dissipative beach) and $23 \mathrm{~mm}$ (on a reflective beach), while in Italy $D$. trunculus matured at $18 \mathrm{~mm}$ (Zeichen et al. 2002). In Turkey, Deval (2009) found a similar size, $19 \mathrm{~mm}$, while in Portugal, Gaspar et al. (1999) reported sizes ranging between 13 and $21 \mathrm{~mm}$, and in Spain the same species started sexual maturity earlier, at $11 \mathrm{~mm}$ for both females and males (Delgado and Silva 2016).

The species of the Donax genus start maturity independently of the climatic environment to which they are subject, within the size interval of 10 to $20 \mathrm{~mm}$. Gaspar et al. (1999) suggested that sexual maturity was a function of age rather than size, so these species would start the reproductive maturity in the first year of life.

The biological variables (mature and spawning stages; oocyte diameters) had no relationship with the environmental parameters, indicating a continuous reproductive cycle, without seasonal influence. This reproductive strategy was confirmed by other methods and indices (frequency of maturation stages, CI, AFDM and oocyte number) indicating continuous spawning. Gil and Thomé (2004a) in Brazil found the same breeding pattern for $D$. hanleyanus, as did Riascos (2006) in Colombia for D. dentifer.

In temperate regions, Herrmann et al. (2009) revealed that $D$. hanleyanus in Argentina shows two annual gametogenic cycles, while $D$. trunculus in Tunisia has an annual reproductive cycle and a single spawning season (Tlili et al. 2011). In Portugal D. trunculus begins to release gametes from March to August (Gaspar et al. 1999). These reproductive patterns compared with those recorded in Ajuruteua Beach corroborate the hypothesis of Giese (1959) that marine invertebrates have a more limited reproduction period in polar and temperate regions and a longer one in the tropics.

Donax striatus shows an opportunist strategy characterized by early gonadal maturation and continuous spawning. This occurs because the energy obtained from the diet is rapidly directed towards gonad maturation and storage in somatic tissue (Cárdenas and Aranda 2000). This strategy has been explained by Defeo and Cardoso (2002), based on the latitudinal gradient hypothesis, according to which benthic organisms from lower latitudes have longer reproductive cycles, and these latitudinal tendencies were related to limited temperature variations, and correlated to high food availability in the coastal zone. This hypothesis was evident in this study, since SST and chlorophyll $a$ showed little variation throughout the study, in part explaining the absence of relationships of AFDM, CI, oocyte abundance, ripe and spawning stages with these environmental variables.

However, in this study there was a slight increase in frequency of individuals in gamete release during the rainy season, which might have occurred due to an increase in food availability caused by a slight increase in organic matter and chlorophyll $a$ (Fig. 2C-D). Herrmann et al. (2009) suggested that phytoplankton biomass has a direct impact on the reproductive cycle of bivalves. Several authors argue that the almost constant temperature in tropical environments favours a high food availability throughout the year, which provides a continuous reproductive cycle in tropical bivalves (Gil and Thomé 2004a, Corte et al. 2014, Rangel et al. 2016). The highest frequency of immature individuals occurred in the dry period (October to November 2015), and such organisms are defined as recruits, since they will still attain the ripe stage.

In conclusion, D. striatus showed characteristics of an r-strategist species and both females and males showed synchronism in the gametogenic evolution and spawning throughout the study period. For species conservation, harvesting should be recommended at an SL above $13 \mathrm{~mm}$. The results highlight that the low variation of environmental parameters provides favourable conditions for an effective reproductive strategy that guarantees reproductive success throughout the year without major events, following the pattern of reproduction postulated for bivalves in tropical environments. However, it is revealed that chlorophyll $a$, rainfall and organic matter intensify the frequency of release of gametes, probably due to the increase in food availability, demonstrated by the significant relation of the organic matter with the CI.

\section{REFERENCES}

Anderson S.C., Mills Flemming J., Watson R., et al. 2011. Rapid Global Expansion of Invertebrate Fisheries: Trends, Drivers, and Ecosystem Effects. PloS ONE 6: 1-9. https://doi.org/10.1371/journal.pone.0014735

Akaike H. 1973. Information theory as an extension of the maximum like lihood principle. In: Petrov B.N., Csáki F. (eds), Proc.2nd Int. Symp. Information Theory, Akadémiai Kiadó, Budapest, pp. 267-281.

Alves M.A.M.S., El-Robrini M. 2006. Morphodynamics of a macrotidal beach: Ajuruteua, Bragança - North Brazil. J. Coast. Res. SI 39: 1848-1850.

Boehs G., Absher T.M., Cruz-Kaled A.C. 2008. Ecologia populacional de Anomalocardia brasiliana (Gmelin, 1791) (Bivalvia, Veneridae) na Baía de Paranaguá, Paraná, Brasil. Bol. Inst. Pesca 34: 259-270.

Brey T. 1986. Formalin and formaldehyde-depot chemicals: Effects on dry weight and ash free dry weight of two marine bivalve species. Meeresforsch 31: 52-57.

Cárdenas E.B., Aranda D.A. 2000. A review of reproductive patterns of bivalve mollusks from Mexico. Bull. Mar. Sci. 66: 13-27.

Companhia de Tecnologia de Saneamento Ambiental (CETESB). 2014. Determinação de Clorofila a e Feofitina a: método espectrofotométrico. Diário Oficial do Estado de São Paulo Caderno Executivo I, v.124 (71) de 15/04/14, Poder Executivo, Seção I, 53-55.

http://cetesb.sp.gov.br/wp-content/uploads/2013/11/L5306.pdf

Corte G.N., Yokoyama L.Q., Amaral A.C.Z. 2014. An attempt to 
extend the Habitat Harshness Hypothesis to tidal flats: A case study of Anomalocardia brasiliana (Bivalvia: Veneridae) reproductive biology. Estuar. Coast. Shelf. S. 150: 136-141. https://doi.org/10.1016/j.ecss.2013.12.007

Dean W.E. 1974. Determination of carbonate and organic matter in calcareous sediments and sedimentary rocks by loss on ignition: comparison with other methods. J. Sediment. Petrol. 44: 242-248.

Defeo O., Cardoso R.S. 2002. Macroecology of population dynamics and life history traits of the mole crab Emerita brasiliensis in Atlantic sandy beaches of South America. Mar. Ecol. Prog. Ser. 239: 169-179. https://doi.org/10.3354/meps239169

Delgado M., Silva L. 2016. Timing variation sand effects of size on there productive output of the wedge clam Donax trunculus (L. 1758) in the littoral of Huelva (SW Spain). J. Mar. Biol. Ass. U.K. 98: 341-350. https://doi.org/10.1017/S0025315416001429

Deval M. C. 2009. Growth and reproduction of the wedge clam (Donax trunculus) in the Sea of Marmara, Turkey. J. Appl. Ichthyol. 25: 551-558 https://doi.org/10.1111/j.1439-0426.2009.01258.x

Fretter V. 1984. Prosobranchs. In: Tompa A.S., Verdonk N.H., van den Biggelaar J.A.M. (eds), The Mollusca. Academic Press, Florida, pp. 1-5.

Galvão M.S.N., Henriques M.B., Pereira O.M., et al. 2006. Ciclo reprodutivo e infestação parasitária de mexilhões Perna perna (Linnaeus, 1758). Bol. Inst. Pesca 32: 59-71.

Gaspar M.B., Ferreira R., Monteiro C.C. 1999. Growth and reproductive cycle of Donax trunculus L., (Mollusca: Bivalvia) off Faro, southern Portugal. Fish. Res. 41: 309-316. https://doi.org/10.1016/S0165-7836(99)00017-X

Giese A.C. 1959. Comparative physiology: annual reproductive cycles of marine invertebrates. Ann. Rev. Physiol. 21: 547-576. https://doi.org/10.1146/annurev.ph.21.030159.002555

Gil G.M., Thomé J.W. 2004a. Descrição do ciclo reprodutivo de Donax hanleyanus (Bivalvia, Donacidae) no sul do Brasil. Iheringia, Sér. Zool. 94: 271-276. https://doi.org/10.1590/S0073-47212004000300008

Gil G.M., Thomé J.W. 2004b. Proporção sexual e comprimento de concha na primeira maturação sexual em Donax hanleyanus Philippi (Bivalvia, Donacidae) no Rio Grande do Sul, Brasil. Rev. Bras. Zool. 21: 345-350. https://doi.org/10.1590/S0101-81752004000200032

Hammer Ø., Harper D.A.T., Ryan P.D. 2001. PAST: Paleontological Statistics Software Package for Education and Data Analysis. Palaeontol Electron. 4: 1-9.

Herrmann M., Barreira C.A.R., Arntz W.E., et al. 2009. Testing the habitat harshness hypothesis: reproductive biology of the wedge clam Donax hanleyanus (Bivalvia: Donacidae) on three Argentinean sandy beaches with contrasting morphodynamics. J. Mollus. Stud. 76: 33-47.

https://doi.org/10.1093/mollus/eyp044
Junqueira L.C., Junqueira L.M.M.S. 1983. Técnicas básicas de citologia e histologia. Livraria e Editora Santos, São Paulo, 123 pp.

Mackie G.L. 1984. Bivalves. In: Tompa A.S., Verdonk N.H., van den Biggelaar J.A.M. (eds), The Mollusca. Academic Press, Florida, pp. 305-418.

Martorano L.G., Pereira L.C., Cézar E.G.M., et al. 1993. Estudos climáticos do Estado do Pará: classificação climática (Koppen) e deficiência hídrica (Thornhtwhite, Mather). Belém, Sudam/ Embrapa/SNLCS, Pará. pp. 261-264.

McCullagh P., Nelder J.A. 1989. Generalized Linear Models. Chapman and Hall/CRC. $2^{\mathrm{a}}$ edition, $532 \mathrm{pp}$.

McLachlan A., Brown A. 2006. Sandy beaches as ecosystems. Elsevier Science Publishers, Amsterdam, $373 \mathrm{pp}$.

Narchi W. 1976. Ciclo anual da gametogênese de Anomalocardia brasiliana (Gmelin, 1791) (Mollusca Bivalvia). Bol. Zool. 1: $331-350$. https://doi.org/10.11606/issn.2526-3358.bolzoo.1976.121588

Nascimento I.A., Lunetta J.E. 1978. Ciclo sexual da ostra de mangue e sua importância para o cultivo. Cien. Cult. 36: 736-742.

Quayle D.B. 1943. Sex, gonad development and seasonal gonad changes in Paphia staminea Conrad. J. Fish. Res. Board. Can. 6: $140-151$. https://doi.org/10.1139/f42-018

R Core Team. 2017. R: A language and environment for statistical computing. R Foundation for Statistical Computing, Version 3.4.3. Vienna, Austria. https://www.R-project.org/

Rangel M.S., Mendoza J., Freites L., et al. 2016. Biometric and reproductive aspects of the pen shell Atrina seminuda (Bivalvia: Pinnidae) in northeastern Venezuela. Molluscan Res. 37: 87-97. https://doi.org/10.1080/13235818.2016.1231303

Riascos J.M. 2006. Effects of El Niño-Southern oscillation on the population dynamics of the tropical bivalve Donax dentifer from Málaga bay, Colombian Pacific. Mar. Biol. 148: 1283-1293. https://doi.org/10.1007/s00227-005-0165-4

Riascos J.M., Urban H.J. 2002. Dinámica poblacional de Donax dentifer (Veneroida: Donacidae) en Bahía Málaga, Pacífico colombiano durante el fenómeno "El Niño" 1997/1998. Rev. Biol. Trop. 50: 1113-1123.

Tlili S., Métais I., Ayache N., et al. 2011. Is the reproduction of Donax trunculus affected by their sites of origin contrasted by their level of contamination? Chemosphere 84: 1362-1370. https://doi.org/10.1016/j.chemosphere.2011.05.009

World Register Marine Species (WORMS). 2018. Donax Linnaeus, 1758 .

http://www.marinespecies.org/aphia.php?p=taxdetails\&id=137906

Zeichen M.M., Agnesi S., Mariani A., et al. 2002. Biology and population dynamics of Donax trunculus L. (Bivalvia: Donacidae) in the South Adriatic Coast (Italy). Est. Coast. Shelf Sci. 54: 971-982.

https://doi.org/10.1006/ecss.2001.0868 